\title{
Framing Media Online atas Pemberitaan Isu Lingkungan Hidup Dalam Upaya Pencapaian Keberhasilan SDGs Indonesia
}

\author{
Xenia Angelica Wijayanto ${ }^{\mathrm{a}, 1}$, Lestari Nurhajati ${ }^{\mathrm{b}, 2}$ \\ a, b Sekolah Tinggi Ilmu Komunikasi LSPR, Jakarta, Indonesia \\ ${ }^{1}$ xenia.aw@1spr.edu; ${ }^{2}$ lestari.n@1spr.edu;
}

Keywords

Framing,

SDGs lingkungan hidup,

Media,

\begin{abstract}
The Sustainable Development Goals (SDGs), that have been carried out by Indonesia, are global programs launched by the United Nations since September 2015. This is proven by the Presidential Regulation No. $59 /$ 2017 about the Implementation of Achievement of Sustainable Development Goals which was inaugurated by President Jokowi in July 2017. Among 17 SDGs points, there are 6 points that talk about environmental issue. This shows the importance of environmental issues that are now a global concern. Information about SDGs to public is still not massive, even though SDGs socialization is very important for the society so that the final goal of SDGs in Indonesia will be successful in 2030. The aim of this study is to find ways for media that can fix current environmental problems and problems experienced by Indonesian SDGs. This study used Environmental Communication concept. For the methodology, this study uses framing from Pan \& Kosicki, with 4 of the most frequently accessed online media in Indonesia, in 2018 namely Detik.com, Tribunnews.com, Kompas.com, and Liputan6.com. Pre-research results show that online media contains very little news about environmental issues in their program, implementation and process of achieving Indonesia's SDGs success.
\end{abstract}

\section{PENDAHULUAN}

Pada bulan September 2015 di Sidang Umum Perserikatan Bangsa-Bangsa (PBB) ke 70 yang diadakan di New York, Amerika Serikat, Indonesia bersama-sama dengan Negara-negara PBB lainnya telah menyepakati komitmen global berupa Tujuan Pembangunan Berkelanjutan atau Sustainable Development Goals (TPB/SDGs) untuk jangka waktu pelaksanaan tahun 2015-2030. SDGs adalah sebuah kelanjutan dari Millenium Development Goals (MDGs) atau Tujuan Pembangunan Milenium yang dijalankan Indonesia dan juga negara-negara PBB secara global pada tahun 2000-2015 dan telah usai pada tahun 2015 lalu. SDGs terdiri atas 17 tujuan dan 169 target yang membidik berbagai isu pembangunan, mulai dari kemiskinan hingga kerja sama internasional (Panuluh dan Fitri, 2016) [1]. Penerapan SDGs di Indonesia diatur dalam Peraturan Presiden Nomor 59 Tahun 2017.

Tujuan global SDGs adalah sebagai berikut: 1) Mengakhiri segala bentuk kemiskinan di mana pun; 2) Menghilangkan kelaparan, mencapai ketahanan pangan dan gizi yang baik, serta meningkatkan pertanian berkelanjutan; 3) Menjamin kehidupan yang sehat dan meningkatkan kesejahteraan seluruh penduduk semua usia; 4) Menjamin kualitas pendidikan yang inklusif dan merata serta meningkatkan kesempatan belajar sepanjang hayat untuk semua; 5) Mencapai kesetaraan gender dan memberdayakan kaum perempuan; 6) Menjamin ketersediaan serta pengelolaan air bersih dan sanitasi yang berkelanjutan untuk semua; 7) Menjamin akses energi yang terjangkau, andal, berkelanjutan, dan modern untuk semua; 8) Meningkatkan pertumbuhan ekonomi yang inklusif dan berkelanjutan, kesempatan kerja yang produktif dan menyeluruh, serta pekerjaan yang layak untuk semua; 9) Membangun infrastruktur yang tangguh, meningkatkan industri inklusif dan berkelanjutan, serta mendorong inovasi; 10) Mengurangi kesenjangan intra dan antarnegara; 11) Menjadikan kota dan permukiman inklusif, aman, tangguh, dan berkelanjutan; 12) Menjamin pola produksi dan konsumsi yang berkelanjutan; 13) Mengambil tindakan cepat untuk mengatasi perubahan iklim dan dampaknya; 14) Melestarikan dan memanfaatkan secara berkelanjutan sumber daya kelautan dan samudera untuk pembangunan berkelanjutan; 15) Melindungi, merestorasi, dan meningkatkan pemanfaatan berkelanjutan ekosistem daratan, mengelola hutan secara lestari, menghentikan penggurunan, memulihkan 
degradasi lahan, serta menghenti-kan kehilangan keanekaragaman hayati; 16) Menguatkan masyarakat yang inklusif dan damai untuk pembangunan berkelanjutan, menyediakan akses keadilan untuk semua, dan membangun kelembagaan yang efektif, akuntabel, dan inklusif di semua tingkatan; 17) Menguatkan sarana pelaksanaan dan merevitalisasi kemitraan global untuk pembangunan berkelanjutan. [2]

17 tujuan di atas dibagi kembali menjadi 4 pilar yaitu pilar pembangunan sosial (5 Tujuan), pembangunan ekonomi (5 Tujuan), pembangunan lingkungan (6 Tujuan) serta pembangunan hukum dan tata kelola (1 Tujuan). Tampak dari uraian tersebut bahwa isu lingkungan merupakan pilar dengan tujuan terbanyak (5 Tujuan) yaitu dalam Tujuan 6 tentang air dan sanitasi, Tujuan 11 tentang kota dan pemukiman, Tujuan 12 tentang produksi dan konsumsi pangan, Tujuan 13 tentang perhubahan iklim, Tujuan 14 tentang kelautan, dan Tujuan 15 tentang darat. Tidak dapat dipungkiri juga bahwa dalam beberapa tujuan lainnya, terdapat juga keterkaitan yang erat dengan isu lingkungan hidup. (Budiantoro, 2017) [3]

Dalam pelaksanaannya, Pemerintah Indonesia telah memasukkan SDGs dalam agenda pembangunan nasional. Hal ini dimulai dengan diintegrasikannya 169 indikator SDGs ke dalam Rencana Pembangunan Jangka Menengah Nasional (RPJM) 2020-2040 (Anggraini, 2017) [4]. Komitmen pemerintah dalam pelaksanaan program SDGs juga dapat dilihat dari gerakan pemerintah dalam membuat pelaksanaan SDGs yang inklusif dan partisipatif baik di tingkat pusat maupun daerah. Pemerintah ingin memastikan bahwa pelaksanaan program SDGs dilakukan dengan semangat transformatif dan no one left behind (Panuluh dan Fitri, 2016) [1]. Untuk itu, Pemerintah mengikut sertakan berbagai pihak stakeholder non- pemerintah untuk terlibat dalam pelaksanaan SDGs seperti kelompok masyarakat sipil, akademisi, filantropi, dan pelaku usaha. Berbeda dengan pelaksanaan MDGs pada tahun 2000 - 2015 lalu yang sangat eksklusif hanya dilakukan oleh pemerintah dan jajarannya.

Dengan kompleksitas permasalahan yang ada tentang SDGs sekarang, mustahil Pemerintah bisa mencapai Tujuan SDGs sendirian. Namun setiap stakeholders yang mau melibatkan diri dalam SDGs perlu untuk mendapatkan pengetahuan yang memadai tentang SDGs dalam konteks memahami detail Tujuan dan Target SDGs, terutama yang relevan dengan peran masing-masing (Jalal, 2017) [5]. Selain itu para pihak juga perlu untuk mengetahui sejauh mana telah dilaksanakannya SDGs di Indonesia.

Media sebagai pilar ke 4 sebuah Negara memiliki peran penting dalam menyebarluaskan informasi. Meskipun perpres sudah ditetapkan sejak 2017 oleh pemerintah, namun sosialisasi dan pelibatan SDGs ke berbagai stakeholder tampak kurang maksimal. Hal ini terbukti dengan sedikitnya informasi dan pemberitaan kegiatan SDGs yang sudah dilakukan oleh kementerian-kementerian di Indonesia. Bagaimana pun juga menjadi sangat penting bagi pemerintah Indonesia untuk secara aktif menginformasikan pelaksanaan SDGs di Indonesia yang dikerjakan oleh berbagai kementerian di Indonesia serta pihak-pihak lain yang turut mendukung pelaksanaan SDGs selama ini. Secara umum, media masa, termasuk di dalamnya media online, akan menginformasikan dan memberitakan berbagai kebijakan pemerintah apabila pelaksanaannya dilakukan secara terbuka, transparan dan berlangsung terus menerus.

Khusus untuk SDGs isu lingkungan, menjadi poin yang menarik karena dalam prakteknya isu ini tidak hanya dikerjakan oleh kementerian lingkungan hidup melainkan juga lintas sektoral seperti pada kementerian sumber daya mineral, energi dan pertambangan, kementerian pertanian, dan lain-lain. Minimnya pemberintaan kinerja pemerintah yang berkaitan dengan program, implementasi dan proses pelaksanaan SDGs memunculkan sebuah permasalahan tersendiri. Padahal seperti yang kita pahami, program SDGs adalah program global yang sudah diratifikasi oleh pemerintah Indonesia untuk dilaksanakan secara berkesinambungan hingga tahun 2030.

Melihat banyaknya isu lingkungan yang masuk dalam SDGs maka menjadi sangat penting memahami juga bagaimana media sebagai pilar ke 4 Negara (selain eksekutif, legislatif dan yudikatif), memberitakan tentang SDGs dengan isu lingkungan. Pertanyaan penelitian yang kemudian muncul adalah bagaimana sesungguhnya framing media online atas pemberitaan SDGs yang berkaitan dengan isu lingkungan.

\section{TINJAUAN PUSTAKA}

\subsection{Integrated Sustainable Development Goals Model}

Sustainable Development Goals (SDGs) adalah kelanjutan dari Millenium Development Goals (MDGs) yang berakhir pada tahun 2015. Berdasarkan Prescott dan Stibbe (2016) dalam Jalal (2017)[5], SDGs berbeda dengan MDGs dalam berbagai hal. Selain yang tampak jelas dari perbedaan Tujuan dan Target, perbedaan utamanya adalah pada pendekatan untuk mencapainya.

SDGs menganut model keberlanjutan mutakhir, bukan lagi pilar yang melihat ekonomi, sosial dan lingkungan secara terpisah atau triple bottom line yang melihat adanya peririsan di antara ketiganya, 
melainkan model nested yang melihat hubungan ketiganya secara komprehensif: ekonomi bagian dari sosial, dan sosial bagian dari lingkungan. Ini berarti SDGs melihat bahwa tak ada tujuan yang terpisah apalagi bertentangan di antara ketiganya. Secara tegas, ini juga berarti hanya bentuk-bentuk ekonomi yang tunduk pada kepentingan sosial dan kelestarian lingkungan yang diperkenankan untuk dibangun dalam periode 2016-2030. (Jalal, 2015) [6]

SDGs membawa 6 prinsip-prinsip mendasar yang menyeimbangkan dimensi ekonomi, sosial, dan lingkungan, yaitu 1) People (manusia), 2) Planet (planet/bumi), 3) Prosperity (kemakmuran), 4) Peace (perdamaian), 5) Justice (keadilan) dan 6) Partnership (kerjasama). Keenam prinsip dasar ini saling berkaitan satu sama lain dan pengelolaan lingkungan hidup merupakan bagian dari 6 elemen essensial tersebut (Jalal, 2015) [6], (KPPPA, 2017) [7]. Sebagai penyempurnaan dari MDGs, SDGs dicanangkan tidak untuk dilakukan hanya oleh pemerintah, namun juga melibatkan berbagai pihak mulai dari kelompok masyarakat sipil, akademisi, filantropi, dan pelaku usaha. Hal ini merupakan perwujudan dari Partnership pada prinsip di atas.

\subsection{Komunikasi Lingkungan}

Kajian tentang komunikasi lingkungan berarti melihat sisi perencanaan serta strategi yang digunakan dalam proses komunikasi dan penyebarannya melalui media. Komunikasi lingkungan ditujukan agar terjadi partisipasi publik dan terlaksananya implementasi program lingkungan hidup yang berkelanjutan (OECD, 1999) [8]. Dari definisi tersebut, dapat dipahami bahwa komunikasi ini merupakan proses interaksi dua arah agar masyarakat memperhatikan faktor-faktor utama dalam persoalan lingkungan hidup dan ruang lingkupnya, serta agar masyarakat paham bagaimana merespon persoalan yang ada (yang berkaitan dengan lingkungan hidup) dengan penuh kompetensi.

Pada pendekatan komunikasi lingkungan, maka banyak peneliti dan praktisi lingkungan melihatnya dengan perspektif komunikasi yang sifatnya dua arah. Ada pemahaman bersama terhadap pesan yang hendak disampaikan oleh komunikator pada komunikan dan termasuk juga hadirnya sebuah umpan balik dalam proses komunikasi tersebut (Jurin, Roush dan Denter, 2010) [9]. Kondisi adanya komunikasi yang partisipatif inilah dianggap sebagai sebuah proses komunikasi lingkungan yang berhasil dan efektif.

Komunikasi lingkungan pun diharapkan membangun secara nyata pengetahuan tentang sistem ekologi dengan campur tangan manusia baik ditingkat lokal, regional dan global. Campur tangan berbagai pihak dalam jenjang tingkatan yang berbeda inilah yang seringkali menyebabkan terjadinya kesejangan proses komunikasi.

Sosialisasi kebijakan lingkungan tidak sekedar berupa interpretasi sederhana dari data ilmiah yang ada, tanpa memperhatikan kebutuhan sosial dari kelompok-kelompok kepentingan yang berbeda. Melainkan juga efektifitas kebijakan ini berhubungan erat dengan dimensi legitimasi sosial yang melibatkan interaksi para ilmuwan, masyarakat, serta para pengambil keputusan (baik di tingkat eksekutif maupun legislatif). Ketiga "pemain utama" ini harus secara berkelanjutan saling berbagi kepedulian dan keahlian mereka untuk berpartisipasi dalam pembangunan, implementasi dam monitoring kebijakan lingkungan hidup, tentu dengan dasar pengetahuan ilmiah tentang isu lingkungan hidup (Senecah, 2004) [10].

Sosialisasi kebijakan lngkungan dan implementasinya kemudian perlu selalu diinformasikan ke publik secara luas dan terus menerus, mengingat hal ini juga menjadi bagian penting dalam proses komunikasi lingkungan yang langsung melibatkan publik.

\subsection{Pemberitaan Media Online}

Pada bagian peran media sebagai salah satu sarana proses komunikasi lingkungan, maka menjadi penting juga mengkaji sejauh apa media sudah menjalankan fungsinya sebagai penyampai informasi yang efektif dan efesien. Dalam situasi era digital saat ini maka posisi media online menjadi sangat signifikan untuk menjadi alat penyampai informasi dan berita.

Perkembangan media online memang sungguh dahsyat, dengan teknologi ini maka perpindahan informasi berjalan sangat cepat. Sehingga menurut Balnaves, Donald, \& Shoesmith (2009) [11], menjadikan dunia ini sangat menglobal dan tidak ada lagi monopoli pengetahuan oleh salah satu pihak. Masyarakat luas, termasuk masyarakat dunia, bisa bertukar informasi dan pengetahuan satu sama lain, tidak ada lagi penguasaan informasi oleh segelintir individu. Dengan demikian semua orang memiliki kesempatan yang sama pula untuk menyampaikan pesan dan pendapatnya ke berbagai penjuru dunia.

Hal serupa dikatakan oleh Burton (2009) [12] yang menjabarkan adanya distribusi kekuatan ketika konvergen pada media digital terjadi. Media digital sebagai pengembangan dari media konvensional awalnya seolah sekadar mengcopy pemberitaan yang ada di suratkabar maupun televisi sebagai media arus utama.

Xenia Angelica Wijayanto et al. (Framing Media Online atas Pemberitaan Isu Lingkungan Hidup....) 
Namun dalam perkembangannya tak jarang media online, terutama news online, kemudian menjadi trendsetter pemberitaan.

\section{METODE PENELITIAN}

Pendekatan penelitian yang digunakan dalam penelitian ini adalah kualitatif. Studi dokumen melalui web dari ke empat media online yakni Tribunnews.com, Detik.com, Liputan6.com, dan Kompas.com. Kemudian teks dokumen pada situs web ke empat media online tersebut, terutama pada isu SDGs lingkungan hidup, dikaji lebih mendalam. Pemilihan media berdasarkan ranking alexa.com yakni yang paling sering di akses pada Januari-Desember 2018. Sementara itu, untuk pemilihan beritanya didasarkan atas posisi teratas pada saat pencarian dengan kata kunci "SDG's Lingkungan Hidup" di mesin pencari masing-masing media online.

Framing yang digunakan menggunakan model Pan dan Kosicki, dengan pengembangan gagasan dari Scheufele (1999) [13]. Di mana Schuefele melihat bahwa proses framing tak lepas dari konstruksi sosial yang ada. Untuk memudahkan proses penelitian, maka analisis data dilakukan menggunakan skema Pan dan Kosicki yang diadaptasi dari penjelasan framing oleh Eriyanto (2005), seperti susunan berikut ini:

Tabel 1. Framing Model Pan dan Kosicki

\begin{tabular}{|c|c|c|c|}
\hline No & Struktur & Perangkat Framing & Unit yang Diamati \\
\hline 1 & $\begin{array}{l}\text { SKEMATIS } \\
\text { Cara wartawan menyusun } \\
\text { fakta }\end{array}$ & Skema berita & $\begin{array}{l}\text { Headline, lead, latar } \\
\text { infrmasi, kutipan sumber } \\
\text { atau pernyataan, penutup. }\end{array}$ \\
\hline 2 & $\begin{array}{l}\text { SKRIP } \\
\text { Cara wartawan } \\
\text { mengisahkan fakta }\end{array}$ & Kelengkapan berita & $5 \mathrm{~W}+1 \mathrm{H}$ \\
\hline 3 & $\begin{array}{l}\text { TEMATIK } \\
\text { Cara wartawan menulis } \\
\text { fakta }\end{array}$ & $\begin{array}{l}\text { 1. Detail } \\
\text { 2. Koherensi } \\
\text { 3. Bentuk kalimat } \\
\text { 4. Kata ganti }\end{array}$ & $\begin{array}{l}\text { Paragraf, proposisi, kalimat, } \\
\text { hubungan antar kalimat. }\end{array}$ \\
\hline 4 & $\begin{array}{l}\text { RETORIS } \\
\text { Cara wartawan } \\
\text { menekankan fakta }\end{array}$ & $\begin{array}{l}\text { 1. Leksikon } \\
\text { 2. Grafis } \\
\text { 3. Metafora }\end{array}$ & $\begin{array}{l}\text { Kata, idiom, gambar/foto, } \\
\text { grafik. }\end{array}$ \\
\hline
\end{tabular}

Diadaptasi dari Eriyanto, 2005 pp. 255-256 [14]

\section{HASIL DAN PEMBAHASAN}

Analisa dilakukan pada 8 berita online yang diambil dari 4 media online dengan rentang waktu pada bulan Januari - Desember 2018. Dari rentang waktu tersebut ditemukan bahwa berita di media online yang memuat kata kunci "SDG's Lingkungan Hidup" tidak terlalu banyak diberitakan. Terbukti pada Detik.com terdapat 26 berita, Tribunnews.com 58 berita, Kompas.com 19 berita dan Liputan6.com 5 berita. Terlihat pula jumlah yang sangat sedikit seperti pada Liputan6.com yang hanya memuat 5 berita dalam kurun waktu satu tahun.

Pada judul berita "Uni Eropa dan Kementerian RI Luncurkan EU-Indonesia Blue Book 2018” [15] yang dimuat di liputan6.com dari sisi Sintaksi/sSkematis tampak bahwa lead diawali dengan menunjukan sikap yang penuh persahabat dari kementerian Bapenas, Kementerian Lingkungan Hidup dan duta Besar Uni Eropa dalam kegiatan “ EU-Indonesia Blue Book 2018” yakni laporan tahunan kerjasama pembangunan antara Uni Eropa dan Indonesia. Pemberitaan ini di latar belakangi tema utama EU-Indonesia Blue Book 2018, yaitu Perubahan Iklim. Sehingga arah pembahasan dari para sumbernya yang dikutip pun tentang isu iklim dan lingkungan hidup. Sumber yang dikutip pun hanya menteri Bappenas Bambang Brodjonegoro dan Dubes Uni Eropa untuk RI; Vincent Guérend. Sementara itu tidak ada kutipan sama sekali dari sumber kementerian lingkungan hidup, Siti Nurbaya Bakar, yang pada awal lead diberitakan hadir pada acara seremoni tersebut. Bahkan kutipan sumber menteri Bappenas pun ditulis oleh wartawannya sebagai bagian dari kutipan rilis resmi pemberitaan. Penutup tulisan wartawannya mencoba memberikan data dan informasi tambahan tentang isu yang diberitakan. Kemudian pada bagian Skrip terbaca bahwa wartawan tidak jelas memberitakan di mana (where) acara tersebut dilakukan, lalu bagaimana (how) acara tersebut berlangsung, 
hanya bersifat seremoni, ataukah ada informasi tentang keberlanjutan kerjasama tersebut? Lalu siapa saja yang terlibat langsung dan tak langsung pada acara tersebut (who). Hal ini tampak dari ketidak konsistenan informasi yang diawal menunjukkan kehadiran meneteri lingkungan hidup, namun sampai akhir berita tidak ditunjukan peran kementerian ini dalam kegiatan kerjasama tersebut. Dari sisi Tematik pun tampak jelas, pemberitaan ini dikerjakan dengan cara terburu-buru. Tidak memperhatikan konsistensi isi tulisan, pun kalimat kutipan yang ada pada bagian akhir tidak mampu menjelaskan maksud dan pesan yang diharapkan dari narasumber secara lebih mendalam. Termasuk pada bagian bantuan Uni Eropa pada propinsi Aceh. Namun tidak dijelaskan keterlibatan kementerian Bapenas dan Kementerian Lingkungan Hidup. Pada bagian Retoris secara eksplisit wartawan hanya mencoba menampilkan kegiatan seremoninya saja, lengkap dengan dua foto seremoninya, namun kembali lagi, tidak mampu menjabarkan ada fakta apa dibalik kegiatan seremoni tersebut.

Pada berita Liputan6.com dengan judul "Sulut Terapkan SDGs Untuk Sejahterakan Rakyat" [16], pada poin Sintaksis/Skematis didapati bahwa berita dibuka dengan kalimat pernyataan yang disampaikan oleh sumber Ketua Badan Kerja Sama Antar-Parlemen (BKSAP) DPR RI Nurhayati Ali Assegaf. Nuansa berita adalah informatif yang memuat informasi tentang pemahaman SDGs secara general dan memberikan input positif tentang pencapaian SDGs hingga saat itu. Dilanjutkan dengan input pandangan Narasumber 2 yaitu Gubernur Sulut tentang harapan pencapaian SDGs di daerahnya. Kutipan-kutipan yang diberikan cukup singkat, dengan beberapa kutipan langsung dan tidak langsung. Pada bagian penutup, disebutkan beberapa orang yang hadir pada acara tersebut lainnya, namun mereka tidak menjadi sumber berita, dan tidak terdapat saran atau kritik dari jurnalis. Dalam hal Skrip, Komponen Where, di mana acara tersebut diadakan tidak ditulis dengan jelas. Demikian juga dengan How, bagaimana acara tersebut dilangsungkan. Pada sisi Tematik, pemberitaan dikerjakan dengan cukup baik, dapat dilihat dari hubungan antar kalimat dan penggunaan kata yang saling berhubungan, juga penjabaran dengan lebih lanjut tentang rencana pemerintah daerah tentang pengembangan SDGs di daerahnya. Pada bagian Retoris, jurnalis meletakkan foto acara rapat dengan keterangan foto yang menjelaskan isi foto tersebut.

Pada berita "Negara Harus Hadir dalam Perencanaan Tata Ruang Nasional" [17] yang diangkat oleh Kompas.com, poin Sintaksis/Skematis dapat dilihat bahwa berita ini memberikan nuansa yang positif tentang perkembangan pembangunan dan tata ruang Negara Indonesia. Terlihat juga bahwa dalam kutipan yang dilakukan, sumber diambil hanya dengan 1orang yaitu Ketua Umum Ikatan Ahli Perencanaan (IAP) Bernardus Djonoputro melalui keterangan tertulis. Dalam hal ini dapat dilihat bahwa data yang diambil adalah hasil dari press release, bukan dari wawancara langsung. Dalam berita ini ditemukan saran kelanjutan tindakan yang harus dilakukan namun dikemukakan bukan oleh jurnalis tapi oleh sumber yang hanya 1 orang. Skrip dengan konteks $5 \mathrm{~W}+1 \mathrm{H}$ memuat cukup lengkap detail yang diperlukan, kembali lagi karena berita diambil dari press release. Pada sisi Tematik, hubungan antar kalimat dan paragraf terlihat baik, dengan penekanan pada isu pembangunan dan nuansa SDGs yang hanya dibahas di akhir berita. Pada bagian Retoris pemberitaan ini dilengkapi dengan foto ilustrasi Stasun Maja, Banten, yang diambil oleh wartawan Kompasnya secara langsung. Namun selebihnya tidak ada dukungan dalam bentuk idiom kata/kalimat.

Pada berita Kompas.com "Indonesia Sodorkan Solusi Persoalan Malnutrisi di Asia dan Pasifik" [18], sisi Sintaksis/Skematis terlihat bahwa headline dan lead berita telah terhubung dengan baik. Diikuti dengan adanya kutipan-kutipan baik secara langsung maupun tidak langsung. Namun menjadi perhatian adalah sumber berita yang terlihat hanya dari 1 sumber. Topik yang diusung dalam berita ini juga mengangkat isu ketahanan pangan, namun yang diceritakan secara mendetail adalah upaya yang dilakukan di taraf internasional. Pada penutup ditemukan harapan dan juga saran yang diberikan kepada lembaga internasional sebagai bentuk upaya mendorong perubahan dan peningkatan kualitas organisasi tersebut. Pada konteks Skrip, cukup lengkap dituliskan dengan detail acara dan juga komposisi $5 \mathrm{~W}+1 \mathrm{H}$ yang dimuat dalam berita. Selanjutnya dalam unsur Tematik, dapat dilihat bahwa jurnalis menuliskan kalimatnya dengan tergesa-gesa, sehingga terasa ruang bergerak pada kalimat tersebut sangat kaku. Penggunaan idiom dilakukan oleh sumber yang dikutip, namun tidak dijelaskan lebih lanjut oleh jurnalis. Data yang disajikan terlihat cukup detail, namun tidak dijelaskan dari mana detail tersebut diambil. Penelusuran pada Retoris ditemukan bahwa berita ini diambil dari release kementerian terkait yang mengikuti acara tersebut. Dibuktikan dengan adanya foto yang kepemilikannya adalah kementerian tersebut.

Tribunnews.com memuat berita dengan judul "Proper LHK Dorong Pelaku Usaha Jalankan Bisnis yang Beretika" [19]. Dari sisi Sintaksis/Skematis tampak bahwa berita dibuka dengan lead yang tidak jelas. Terlihat dari kalimat yang janggal 'Menteri Lingkungan Hidup dan Kehutanan (LHK), Siti Nurbaya Bakar menegaskan, Program Penilaian Peringkat Kinerja Perusahaan atau Proper adalah trigger, tools dari Pemerintah untuk mendorong para pelaku usaha menjalankan aktivitas bisnis yang beretika, berwawasan

Xenia Angelica Wijayanto et al. (Framing Media Online atas Pemberitaan Isu Lingkungan Hidup....) 
lingkungan dan bertanggung jawab.' Penulisan dirasa terburu-buru sehingga korelasi antar kalimat menjadi berkurang. Berita dibagi menjadi 2 bagian yang pada part pertama memberitakan pelaksanaan Proper Kementerian LHK 2018 yang dibuka oleh Menteri LHK, Siti Nurbaya, sedangkan pada bagian kedua memberitakan informasi tentang para perusahaan pemenang penghargaan tersebut. Nuansa dan arah berita menceritakan tentang penerapan program SDGs oleh perusahaan-perusahaan dalam upaya mendukung pelestarian lingkungan. Narasumber yang diambil adalah Menteri LHK dan Dirjen Pengendalian Pencemaran dan Kerusakan Lingkungan, masih dari kementerian yang sama. Terdapat pengulangan dan penekanan tentang SDGs dalam berita ini. Pada bagian Skrip, unsur 5W+1H terpenuhi dalam berita ini, dibantu dengan pengambilan data dari press release yang sangat mendetail mengenai para penerima penghargaan. Bagian Tematik, sangat disayangkan bahwa pada penutup tidak ditemukan saran ataupun kritik dari berita ini yang dituliskan oleh jurnalis, ataupun pengelaborasian lebih lanjut dari kutipan-kutipan yang dimuat. Tampak dengan sangat jelas bahwa sebagian besar berita diambil dari press release kementerian terkait karena pada pengutipan dan hubungan antar kalimat sedikit janggal, terlebih pada pemisahan bagian ke halaman berikutnya. Pada bagian Retoris, jurnalis mencantumkan foto dengan caption yang kurang menjelaskan isi foto karena tidak menjelaskan secara spesifik moment pada foto tersebut, hanya penjelasan general bahwa Menteri ada pada foto tersebut, namun untuk keperluan apa Beliau berada di panggung dan siapa beberapa orang lainnya.

Pada artikel berita Tribunnews.com dengan judul "Menteri LHK: Penanganan Global Pencemaran Laut Makin Penting" [20], secara Skematis dapat dilihat bahwa headline berita merupakan kalimat pernyataan dari narasumber utama berita ini. Pada lead berita terlihat adanya sinergi dari berbagai organisasi internasional dan juga kementerian LHK dalam mempersiapkan IGR Meeting yang akan diselenggarakan saat itu. Tema berita adalah perhatian KLHK dan juga dunia internasional tentang isu polusi air (dalam hal ini laut) dan juga udara dan sampah plastik serta pentingnya IGR Meeting bagi negara-negara serta kesiapan Indonesia dalam menyelenggarakan acara tersebut. Sumber berita serta kutipan hanya satu, yaitu Menteri KLHK Siti Nurbaya meskipun pada awal berita telah disebutkan cukup banyak pihak yang hadir dalam rapat persiapan tersebut. Terlihat juga penekanan mengenai komitmen Indonesia dalam hal ini melalui KLHK tentang pelaksanaan SDGs lingkungan dengan kolaborasi berbagai stakeholders pada bagian penutup. Bagian Skrip terlihat bahwa unsur $5 \mathrm{~W}+1 \mathrm{H}$ mengenai acara tersebut dijabarkan oleh jurnalis dengan cukup lengkap dengan penyebutan beberapa contoh oleh Menteri LHK. Pada poin Tematik, kalimat-kalimat yang tertulis tampak dicantumkan tanpa kematangan penulisan. Terlihat dengan kurang jelasnya perbedaan antara kalimat kutipan, langsung dan tidak langsung, serta banyak kalimat yang tidak berhubungan atau tanpa kata penghubung seperti pada paragraph yang dimulai dengan kata "Menurut Siti Nurbaya..." dan ditutup dengan dua kalimat janggal yang mungkin sebenarnya berhubungan "...Juga penting untuk proses belajar dan tukar pengalaman dalam kerjasama, penguatan kebijakan dll; penguatan inisiatif program/kegiatan secara nyata dan langkah-langkah aksi lapangannya. Kita berharap hasil yang baik dari IGR-4 ini." Kalimat-kalimat tersebut tidak menggunakan pengutipan yang baik sehingga sangat rancu apakah ini adalah fakta keterangan dari Menteri atau pendapat/analisa/harapan dari jurnalis. Kalimat kutipan hanya terdapat pada akhir berita sebagai penutup. Pada bagian Retoris, penekanan fakta kurang didapatkan pada kalimat-kalimat yang digunakan. Namun demikian terdapat foto acara yang dilampirkan pada berita tersebut yang menggambarkan keadaan saat rapat berlangsung, meskipun caption yang dituliskan oleh jurnalis hanya menyebutkan "Menteri Lingkungan Hidup dan Kehutanan (LHK), Siti Nurbaya" sedangkan di dalam foto terdapat banyak orang.

Pada artikel Detik.com yang berjudul "Ketaatan Perusahaan soal Pengelolaan Lingkungan Hidup Capai 87\%" [21], secara Sintaksis/Skematis headline dan lead berita telah sejalan. Penjabaran dari headline telah diberikan pada lead, sehingga pembukaan berita mengalir dengan baik. Pengutipan keterangan dan data angka serta istilah pada artikel ini cukup lengkap, dengan langsung mengambil dari press release kementerian KLH. Mengingat bahwa media memiliki kecenderungan untuk mengutip langsung apa yang tertulis dalam press release, data yang diberikan pada berita ini terbilang cukup lengkap dan menggambarkan dengan cukup jelas bahwa terdapat peningkatan yang signifikan atas jumlah perusahaan yang mematuhi etika pelestarian lingkungan, serta perusahaan yang menerapkan SDGs. Terlihat pula bahwa penyampaian berita tidak hanya diambil berita baik namun juga jumlah pelanggaran yang terjadi sehingga berita menjadi berimbang. Unsur kebaharuan berita dan keistimewaan informasi juga terdapat di berita ini. Sumber berita pada artikel ini hanya 1 orang yaitu Menteri KLH. Penutup berita merupakan informasi tentang Proper yang diambil dari release dan tidak memberikan kejelasan kelanjutan dari acara tersebut ataupun kritik dan saran dari jurnalis. Pada bagian Skrip, cara jurnalis menuturkan poin $5 \mathrm{~W}+1 \mathrm{H}$ terlihat lebih luwes dan komprehensif, meskipun tidak menjabarkan data perusahaan penerima penghargaan ataupun perusahaan pelanggar secara detail. Secara Tematik, penulisan fakta dilakukan dengan menulis ulang dari press release.

Xenia Angelica Wijayanto et al. (Framing Media Online atas Pemberitaan Isu Lingkungan Hidup....) 
Kutipan langsung hanya terdapat 2 yaitu pada bagian tengah berita. Hubungan antar kalimat dan paragraf baik dan mengalir sehingga memudahkan untuk mengerti isi berita, serta tidak terjadi pengutipan berulangulang dan penjelasan ulang kutipan. Pada poin Retorik, untuk memperkaya berita, jurnalis mencantumkan sebuah foto, namun foto yang digunakan adalah foto yang sama persis dimuat oleh Tribunnews.com, yang dikeluarkan oleh KLHK sehingga dirasakan tidak ada poin keaslian materi. Caption pada foto tersebut pun tidak menjelaskan isi foto. Dalam poin ini terasa bahwa foto yang digunakan menjadi kurang bervariasi dengan media lainnya dan sekedar mencantumkan foto sebagai pemanis.

Pada artikel berita terakhir, Detik.com menggunakan judul "KLHK: 437 Perusahaan di Indonesia Berpredikat Hijau Emas" [22]. Pada bagian Sintaksis/Skematis, headline berita bila sekilas dibaca memberikan nuansa netral cenderung positif, namun ketika membaca lead berita tersebut maka akan didapati bahwa berita dibuka dengan fakta yang memprihatinkan. Pernyataan-pernyataan diberikan oleh sumber yang pada artikel ini adalah Direktur Jenderal Pengendalian Pencemaran dan Kerusakan Lingkungan KLHK, Karliansyah. Pengutipan informasi dalam berita ini juga menggunakan berbagai macam cara baik secara langsung maupun tidak langsung. Sumber tercantum dengan baik. Secara garis besar berita ini memberikan gambaran positif dan negative perkembangan industri di Indonesia yang mulai mendukung kebijakan pemerintah dalam mensukseskan SDGs. Nuansa informasi positif dirasakan melalui kalimat pendukung di bagian tengah sampai akhir berita ini. Pada bagian penutup, solusi peningkatan kualitas lingkungan hidup serta semangat positif dalam menjalankan pelestarian lingkungan hidup dituangkan oleh jurnalis, meskipun berupa kutipan dari pernyataan sumber. Bagian Skrip pada berita ini memuat $5 \mathrm{~W}+1 \mathrm{H}$ dengan lengkap meskipun tidak tersusun dengan sistematis. Penjelasan dari setiap unsurnya juga dapat dilihat dengan cukup mudah. Pada bagian Tematik, kalimat-kalimat dalam paragraph tersusun dengan teratur dan menggunakan kata-kata yang mudah dipahami meskipun beberapa istilah atau singkatan tidak diberikan kepanjangannya. Secara keseluruhan artikel berita dan paragraf teratur dan berkesinambungan. Pada bagian Retorik, jurnalis memberikan sebuah foto sebagai pelengkap dengan gambar sumber berita sedang memberikan pidato di podium sesuai dengan konteks acara saat berita diambil. Meskipun tidak dapat menjelaskan dan menggambarkan acara yang berlangsung namun cukup mewakili sumber yang diambil.

Tabel 2. Ringkasan Analisa

\begin{tabular}{|l|l|l|l|l|}
\hline $\begin{array}{l}\text { Sumber } \\
\text { berita/Judul }\end{array}$ & $\begin{array}{l}\text { Skematis } \\
\text { Cara wartawan } \\
\text { menyusun fakta } \\
\text { (Skema berita diamati } \\
\text { dari headline, lead, latar } \\
\text { informasi, kutipan } \\
\text { sumber atau pernyataan, } \\
\text { penutup). }\end{array}$ & $\begin{array}{l}\text { Skrip } \\
\text { Cara wartawan } \\
\text { mengisahkan } \\
\text { fakta } \\
\text { (kelengkapan } \\
\text { berita diamati } \\
\text { dari 5W + 1H). }\end{array}$ & $\begin{array}{l}\text { Tematik } \\
\text { Cara wartawan } \\
\text { menulis fakta } \\
\text { (Detil penulisan } \\
\text { diamati dari } \\
\text { paragraf, } \\
\text { proposisi, kalimat, } \\
\text { hubungan antar } \\
\text { kalimat). }\end{array}$ & $\begin{array}{l}\text { Retorik } \\
\text { Cara wartawan } \\
\text { menekankan fakta } \\
\text { (Leksikon, grafis, } \\
\text { metafora yang } \\
\text { diamati ada } \\
\text { tidaknya idiom, } \\
\text { gambar/foto, grafik } \\
\text { dan pendukung }\end{array}$ \\
lainnya).
\end{tabular}




\begin{tabular}{|c|c|c|c|c|}
\hline & & $\begin{array}{l}\text { bagaimana } \\
\text { acara tersebut } \\
\text { dilangsungkan. }\end{array}$ & & \\
\hline $\begin{array}{l}\text { Kompas.com } \\
\text { Negara Harus } \\
\text { Hadir dalam } \\
\text { Perencanaan Tata } \\
\text { Ruang Nasional }\end{array}$ & $\begin{array}{l}\text { Headline berita jelas } \\
\text { dengan lead yang sesuai. } \\
\text { Penyajian data berupa } \\
\text { kutipan cukup dilakukan } \\
\text { dan penutup diberikan } \\
\text { pandangan dan } \\
\text { perencanaan kedepan. }\end{array}$ & $\begin{array}{l}\text { Komponen } \\
5 \mathrm{~W}+1 \mathrm{H} \\
\text { tercantum } \\
\text { dengan bentuk } \\
\text { kutipan. }\end{array}$ & $\begin{array}{l}\text { Hubungan antar } \\
\text { kalimat baik, } \\
\text { dengan kutipan- } \\
\text { kutipan langsung. }\end{array}$ & $\begin{array}{lr}\text { Terdapat foto } \\
\text { dengan caption yang } \\
\text { senada dan } \\
\text { menjelaskan isi } \\
\text { foto. }\end{array}$ \\
\hline $\begin{array}{l}\text { Kompas.com } \\
\text { Indonesia } \\
\text { Sodorkan Solusi } \\
\text { Persoalan } \\
\text { Malnutrisi di Asia } \\
\text { dan Pasifik }\end{array}$ & $\begin{array}{l}\text { Lead dan headline berita } \\
\text { sudah sejalan. Penutup } \\
\text { memberikan saran dan } \\
\text { masukan bagi kemajuan } \\
\text { organisasi. }\end{array}$ & $\begin{array}{l}5 \mathrm{~W}+1 \mathrm{H} \text { cukup } \\
\text { lengkap namun } \\
\text { kurang } \\
\text { dijabarkan } \\
\text { mendetail. }\end{array}$ & $\begin{array}{l}\text { Pemberitaan } \\
\text { dilakukan dengan } \\
\text { kurang } \\
\text { memperhatikan } \\
\text { detail antar } \\
\text { kalimat dan } \\
\text { paragraf. }\end{array}$ & $\begin{array}{l}\text { Foto delegasi } \\
\text { Indonesia di acara } \\
\text { tersebut } \\
\text { dicantumkan untuk } \\
\text { memberikan impresi } \\
\text { positif, dengan } \\
\text { dokumentasi milik } \\
\text { kementerian terkait. }\end{array}$ \\
\hline $\begin{array}{l}\text { Tribunnews.com } \\
\text { Proper LHK } \\
\text { Dorong Pelaku } \\
\text { Usaha Jalankan } \\
\text { Bisnis yang } \\
\text { Beretika }\end{array}$ & $\begin{array}{l}\text { Headline jelas namun } \\
\text { lead tidak jelas. Kutipan } \\
\text { wawancara dan } \\
\text { pernyataan dari } \\
\text { narasumber ada. Data } \\
\text { pendukung dilampirkan } \\
\text { di halaman } 2 \\
\text { pemberitaan dengan } \\
\text { penutup yang kurang } \\
\text { memberikan saran. }\end{array}$ & $\begin{array}{l}\text { Komponen } 5 \mathrm{~W} \\
+1 \mathrm{H} \text { lengkap } \\
\text { tertulis. }\end{array}$ & $\begin{array}{l}\text { Hubungan antar } \\
\text { paragraf kurang } \\
\text { jelas, terlebih pada } \\
\text { hubungan antar } \\
\text { halaman dalam } \\
\text { pemuatan artikel. }\end{array}$ & $\begin{array}{l}\text { Terdapat foto acara } \\
\text { sebagai pendukung, } \\
\text { namun caption foto } \\
\text { kurang menjelaskan. }\end{array}$ \\
\hline $\begin{array}{l}\text { Tribunnews.com } \\
\text { Menteri LHK: } \\
\text { Penanganan } \\
\text { Global } \\
\text { Pencemaran Laut } \\
\text { Makin Penting }\end{array}$ & $\begin{array}{l}\text { Headline berita dan lead } \\
\text { berita sudah sesuai } \\
\text { dengan isi. Penutup } \\
\text { terdapat saran yang } \\
\text { dikutip dari pendapat } \\
\text { narasumber berita } \\
\text { terutama di halaman ke2 } \\
\text { dari artikel, bukan } \\
\text { merupakan saran dari } \\
\text { jurnalis. }\end{array}$ & $\begin{array}{l}\text { Komponen } 5 \mathrm{~W} \\
+1 \mathrm{H} \text { lengkap } \\
\text { tertulis. }\end{array}$ & $\begin{array}{lr}\text { Hubungan } & \text { antar } \\
\text { kalimat } & \text { cukup } \\
\text { baik. } & \end{array}$ & $\begin{array}{l}\text { Terdapat foto acara } \\
\text { sebagai pendukung } \\
\text { namun caption tidak } \\
\text { menjelaskan isi } \\
\text { foto. }\end{array}$ \\
\hline $\begin{array}{l}\text { Detik.com } \\
\text { Ketaatan } \\
\text { Perusahaan soal } \\
\text { Pengelolaan } \\
\text { Lingkungan } \\
\text { Hidup Capai } 87 \%\end{array}$ & $\begin{array}{l}\text { Headline dan lead berita } \\
\text { telah sejalan. Kutipan- } \\
\text { kutipan data dan } \\
\text { pernyataan yang diambil } \\
\text { dari keterangan tertulis } \\
\text { dan lisan dicatatkan } \\
\text { dengan baik, tidak hanya } \\
\text { dari } 1 \text { narasumber. } \\
\text { Penutup tidak } \\
\text { memberikan kritik/saran. }\end{array}$ & $\begin{array}{l}5 \mathrm{~W}+1 \mathrm{H} \\
\text { dalam berita } \\
\text { ini cukup } \\
\text { lengkap. }\end{array}$ & $\begin{array}{l}\text { Hubungan antar } \\
\text { kalimat dan } \\
\text { paragraf dalam } \\
\text { artikel ini baik. }\end{array}$ & $\begin{array}{l}\text { Terdapat foto pada } \\
\text { saat acara } \\
\text { berlangsung sebagai } \\
\text { penegas berita. }\end{array}$ \\
\hline $\begin{array}{l}\text { Detik.com } \\
\text { KLHK: } 437 \\
\text { Perusahaan di } \\
\text { Indonesia } \\
\text { Berpredikat Hijau } \\
\text { Emas }\end{array}$ & $\begin{array}{l}\text { Headline dan lead berita } \\
\text { sejalan. Pengutipan } \\
\text { pernyataan dilakukan } \\
\text { dengan baik. Penutup } \\
\text { yang digunakan adalah } \\
\text { pernyataan dari } \\
\text { narasumber. Tidak ada } \\
\text { saran/kritik dari jurnalis }\end{array}$ & $\begin{array}{l}5 \mathrm{~W}+1 \mathrm{H} \\
\text { dalam berita } \\
\text { ini lengkap } \\
\text { terpenuhi. }\end{array}$ & $\begin{array}{l}\text { Hubungan antar } \\
\text { kalimat baik. } \\
\text { Terjadi banyak } \\
\text { penegasan dan } \\
\text { pembahasaan } \\
\text { ulang dari } \\
\text { pernyataan } \\
\text { narasumber. }\end{array}$ & $\begin{array}{l}\text { Terdapat foto } \\
\text { Direktur Jenderal } \\
\text { sebagai penegas } \\
\text { acara/ yang } \\
\text { memberikan } \\
\text { statement. }\end{array}$ \\
\hline
\end{tabular}

Sumber: data olahan peneliti 2019 


\section{SIMPULAN DAN SARAN}

Dari pemberitan media-media di atas tampak bahwa isu lingkungan masih menjadi "anak tiri" pemberitaan. Terlebih lagi isu SDG's pun seolah bukan prioritas pemberitaan di berbagai media online yang ada. Terbukti dari sedikitnya jumlah liputan dengan isu SDG's dan lingkungan hidup.

Demikian pula dengan pembingkaian (framing) beritanya, tampak bahwa tidak ada keseriusan pihak wartawan dan media dalam pemberitaan tentang isu SDG's dan lingkungan hidup. Hal ini tampak dari liputan pemberitaannya rata-rata berasal dari kegiatan kerjasama, rapat dinas, pemberian penghargaan yang kesemuanya itu bersifat seremonial belaka. Padahal ini merupakan liputan yang pada mesin pencari berada pada urutan teratas dari relevansi isu pemberitaan yang sesuai dengan kata kunci "SDG's Lingkungan Hidup".

Kurang seriusnya liputan isu SDG's dan ligkungan hidup ini juga tampak ketika keempat media yang diteliti semuanya cenderung menangkat isu SDG's Lingkungan Hidup dari rilis resmi penggagas acara/ peserta acara, tanpa adanya check and re-check pada narasumbernya secara langsung.

Saran dalam penelitian ini adalah diperlukannya pelibatan media dengan lebih baik karena media seharusnya dilibatkan lebih banyak dalam isu ini, terutama karena dalam isu SDGs yang diutamakan adalah kolaborasi dan pelibatan lebih luas pada masyarakat dan organisasi sipil. Untuk itu diperlukan pemahaman melalui sosialisasi dan pelatihan lebih lanjut kepada pihak media, perihal pemuatan berita dan penyebaran informasi tentang SDGs.

\section{DAFTAR PUSTAKA}

[1] Panuluh, Sekar, \& Fitri, Meilia R. (2016). Perkembangan Pelaksanaan Sustainable Development Goals (SDGs) di Indonesia. https://www.sdg2030indonesia.org/an-component/media/uploadbook/Briefing_paper_No_1_SDGS_-2016-Meila_Sekar.pdf

[2] Bappenas. 2015. Siaran Pers Komitmen Serius Indonesia Dalam Melaksanakan Sustainable Development Goals 2015-2030.

https://www.bappenas.go.id/files/9915/0397/6784/Siaran_Pers_Komitmen_Serius_Indonesia_dalam_ Melaksanakan_Sustainable_Development_Goals_2015-2030.pdf

[3] Budiantoro, Setyo. 2017. Metadata untuk Penyusunan Rencana Aksi yang Partisipatif. https://www.sdg2030indonesia.org/an-component/media/upload-book/Setyo_Budiantoro__Sekretariat_SDGS.pdf

[4] Anggraini, Amelia. 2017. Indonesia dan SDGs. https://mediaindonesia.com/read/detail/124290indonesia-dan-sdgs

[5] Jalal. 2017. Menguatkan Masyarakat untuk Menggapai SDGs. http://www.hijauku.com/2018/02/28/menguatkan-masyarakat-untuk-menggapai-sdgs/

[6] Jalal. 2015 . Lingkungan dalam Logika Keberlanjutan SDGs. https://www.mongabay.co.id/2015/11/12/opini/

[7] KPPPA. 2017. Press Release Peran Perempuan untuk Kelestarian Sumber Daya Air. https://www.kemenpppa.go.id/index.php/page/read/29/1493/peran-perempuan-untuk-kelestariansumber-daya-air

[8] OECD. 1999. Environmental Communication Applying Communication Tools Towards Sustainable Development, Working Paper of the Working Party on Development Cooperation and Environment. Paris: OECD Publications.

[9] Jurin, Richard R., Donny Roush, Jeff Danter. 2010. Environmental Communication Skills and Principles for Natural Resource Managers, Scientists, and Engineers, Second Edition. New York: Springer. 
[10] Senecah, Susan L. 2004. The Environmental Communication Yearbook, Volume 1. New York: Lawrence Erlbaum Associates, Inc., Publishers

[11] Balnaves, Mark., Stephanie Hemelryk Donald \& Brian Shoesmith. 2009. Media Theories \& Approaches; A Global Perspective. London: Palgrave Macmillan

[12] Burton, Graeme. 2009. Media and Society; Critical Perspectives. India: Rawat Publication.

[13] Scheufele, Dietram A. (1999). Framing as a Theory of Media Effects. Journal of Communication, vol, 49, no. 1. USA: International Communication Association.

[14] Eriyanto. 2005. Analisis Framing; Konstruksi, Ideologi dan Politik Media, Yogyakarta: LKIS Pelangi Aksara

[15] Liputan6.com. 2018. Uni Eropa dan Kementerian RI Luncurkan EU-Indonesia Blue Book 2018. https://www.liputan6.com/global/read/3538596/uni-eropa-dan-kementerian-ri-luncurkan-eu-indonesia$\underline{\text { blue-book-2018 }}$

[16] Anindyati, Hidya. 2018. Sulut Terapkan SDGs Untuk Sejahterakan Rakyat. https://www.liputan6.com/news/read/3437529/sulut-terapkan-sdgs-untuk-sejahterakanrakyat? source=search

[17] Rahmadiani, Arimbi. 2018. Negara Harus Hadir dalam Perencanaan Tata Ruang Nasional. https://properti.kompas.com/read/2018/01/30/164421221/negara-harus-hadir-dalam-perencanaan-tataruang-nasional?page $=1$

[18] Budi, Kurniasih. 2018. Indonesia Sodorkan Solusi Persoalan Malnutrisi di Asia dan Pasifik. https://ekonomi.kompas.com/read/2018/06/06/211929026/indonesia-sodorkan-solusi-persoalan$\underline{\text { malnutrisi-di-asia-dan-pasifik }}$

[19] Simanjuntak, Johnson. 2018. Proper LHK Dorong Pelaku Usaha Jalankan Bisnis yang Beretika. http://www.tribunnews.com/nasional/2018/12/28/proper-lhk-dorong-pelaku-usaha-jalankan-bisnisyang-beretika

[20] Simanjuntak, Johnson. 2018. Menteri LHK: Penanganan Global Pencemaran Laut Makin Penting, http://www.tribunnews.com/nasional/2018/10/26/menteri-lhk-penanganan-global-pencemaran-lautmakin-penting

[21] Reisha, Tia. 2018. Ketaatan Perusahaan soal Pengelolaan Lingkungan Hidup Capai 87\%. https://news.detik.com/berita/d-4362446/ketaatan-perusahaan-soal-pengelolaan-lingkungan-hidup$\underline{\text { capai-87 }}$

[22] Putra, Wisma. 2018. KLHK: 437 Perusahaan di Indonesia Berpredikat Hijau Emas. https://news.detik.com/berita-jawa-barat/d-4332774/klhk-437-perusahaan-di-indonesia-berpredikat$\underline{\text { hijau-emas }}$ 